\title{
Spontaneous resolution of secondary amenorrhoea in a patient with mosaic Turner's Syndrome
}

\begin{abstract}
Mamoojee $\mathrm{Y}^{1}$, Jones $\mathrm{P}^{1}$, Stewart $\mathrm{J}^{2}$, Choudhary $\mathrm{M}^{2}$ \& Quinton $\mathrm{R}^{1}$
1. Department of Endocrinology, Newcastle-upon-Tyne Hospitals, UK, 2. Newcastle Fertility Centre at Life, Newcastle-upon-Tyne Hospitals, UK
\end{abstract}

\section{Background}

Turner's Syndrome (TS) results from a genetic abnormality in phenotypical female individuals where the second $\mathrm{X}$ chromosome is either absent or present in a mosaic form. The most obvious consequences are short stature and primary amenorrhoea, although there are often dysmorphic features as well as cardiovascular complications (Table 1).

$90 \%$ of TS patients experience primary gonadal failure and subsequent infertility. Whilst primary amenorrhoea and pubertal failure is most prevalent, a minority of TS patients may present with secondary amenorrhea after either complete or arrested puberty. The latter is more likely to occur in mosaic forms of TS. Normal puberty, persistent menstruation and unassisted natural conception have all been previously documented in a minority of TS patients (1). With this variable degree of ovarian dysfunction, histologic studies suggest that normal numbers of primordial germ cells, up to 6 weeks' gestation, are subsequently subjected to an accelerated apoptotic process with advancing gestation, by a yet unknown mechanism (2).

Spontaneous recovery of ovarian function after primary ovarian failure in patients with TS has not been previously described in the literature as per our knowledge.

\section{Case report}

A 26-year-old female with mosaic TS developed secondary amenorrhoea by 21 years of age. Of note she had a history of Graves' thyroid disease in childhood (serum TSH-receptor antibody level $66 \mathrm{IU} / \mathrm{L}$ (>1.5 considered positive)), treated with a total thyroidectomy (histology consistent with Graves' disease). Her serum estradiol level was undetectable $(<60 \mathrm{pmol} / \mathrm{L})$ and corresponding $\mathrm{FSH}$ and $\mathrm{LH}$ levels were $101 \mathrm{IU} / \mathrm{L}$ and $52.7 \mathrm{IU} / \mathrm{L}$ respectively (post-menopausal range $>30$ ). Her serum TSH level was $1.63 \mathrm{mIU} / \mathrm{L}$ (normal range 0.3 -4.7 ) on levothyroxine replacement. She was started on hormone replacement therapy (HRT).

She later elected to have fertility treatment and two invitro fertilization (IVF) attempts, using donated eggs from her sister, were unsuccessful. During her second IVF attempt she was noted to have some underlying ovarian activity on ultrasound scanning. She was thus advised to stop her HRT. By 3 months she has had 2 menstrual cycles. Her $\mathrm{AMH}$ was detectable at $8.3 \mathrm{pmol} / \mathrm{L}$ and her last menstrual cycle was ovulatory with a day 21 serum progesterone level of $113 \mathrm{nmol} / \mathrm{L}$. Her corresponding serum $\mathrm{LH}, \mathrm{FSH}$ and estradiol levels at the time were 3.5 $\mathrm{IU} / \mathrm{L}, 4.2 \mathrm{IU} / \mathrm{L}$ and $425 \mathrm{pmol} / \mathrm{L}$ respectively. She later conceived naturally.

\begin{tabular}{|c|c|}
\hline & $\begin{array}{l}\text { Table 1: Characteristic clinical } \\
\text { abnormalities and complications in TS }\end{array}$ \\
\hline & $\begin{array}{l}\text { Skeletal defects with an incidence of } \geq 50 \% \\
\text { Short stature } \\
\uparrow \text { upperlower segment } \\
\text { Dental defects } \\
\text { Cubitus valgus } \\
\text { kyphosis }\end{array}$ \\
\hline & $\begin{array}{l}\text { Cardiac malformations } \\
\text { Aortic valve abnomalities (mostly } \\
\text { bicuspic AoV) } \\
\text { Dilated ascending aortic } \\
\text { Coarctation of aorta } \\
\text { Pulmonary venous abnormalities } \\
\text { Hypertension } \\
\text { Renal and renovascular anomalies }\end{array}$ \\
\hline & $\begin{array}{l}\text { Auditory abnormalities } \\
\text { Recurrent otitis media } \\
\text { Sensorineural and } \\
\text { hearing loss }\end{array}$ \\
\hline & $\begin{array}{c}\text { Visual abnormalities } \\
\text { Myopia } \\
\text { Strabismus }\end{array}$ \\
\hline
\end{tabular}

\section{Discussion}

Although her previously-documented ovarian insufficiency was ascribed to TS, her past history of autoimmune Graves' thyroid disease may explain a propensity to autoimmune ovarian insufficiency, which unlike that arising directly from TS, is known to remit and relapse. In TS patients with ovarian insufficiency and other underlying autoimmune diseases, consideration should be given to possible recovery of ovarian function prior to attempting fertility treatment due to the possibility of autoimmune ovarian insufficiency being a confounding aetiology.

\section{References}

Mortensen KH, Andersen NH, Gravholt CH. Cardiovascular phenotype in Turner syndrome--integrating cardiology, genetics, and endocrinology. Endocr Rev 2012; 33:677.

Pasquino AM, Passeri F, Pucarelli I, et al. Spontaneous pubertal development in Turner's syndrome. Italian Study Group for Turner's Syndrome. J Clin Endocrinol Metab 1997; 82:1810.

Singh RP, Carr DH. The anatomy and histology of XO human embryos and fetuses. Anat Rec 1966; 155:369.

Sylvén L, Hagenfeldt K, Bröndum-Nielsen K, von Schoultz B. Middleaged women with Turner's syndrome. Medical status, hormonal treatment and social life. Acta Endocrinol (Copenh) 1991; 125:359. 